\title{
Understanding the spatial variability in catchment dynamics: a case study of 107 stream catchments in Victoria, Australia
}

\author{
$\underline{\text { A. Lintern }}^{\text {a }}$, J.A. Webb ${ }^{\mathrm{a}}$, D. Ryu ${ }^{\mathrm{a}}$, S. Liu ${ }^{\mathrm{a}}$, U. Bende-Michl ${ }^{\mathrm{b}}$, M. Watson ${ }^{\mathrm{b}}$, D. Waters ${ }^{\mathrm{c}}$, P. Leahy ${ }^{\mathrm{d}}$, \\ P. Wilson ${ }^{\mathrm{e}}$, A.W. Western ${ }^{\mathrm{a}}$ \\ ${ }^{a}$ Department of Infrastructure Engineering, The University of Melbourne, Parkville, Victoria \\ ${ }^{b}$ Bureau of Meteorology, Melbourne, Victoria \\ ${ }^{c}$ Queensland Department of Natural Resources and Mines, Toowoomba, Queensland \\ ${ }^{d}$ Applied Sciences Group, EPA Victoria, Macleod, Victoria \\ e Department of Environment, Land, Water \& Planning, East Melbourne, VIC, 3002
}

Email: a.lintern@unimelb.edu.au

\begin{abstract}
Rivers and streams around the world are being affected by declining water quality. When designing remediation strategies, we must first understand the key factors affecting spatial and temporal variability in stream water quality. As such, the objective of this investigation was to investigate the relationships between in-stream constituent concentrations and streamflow and to understand how these relationships vary across space. We intend to use these findings to add a temporal component into existing statistical models of spatial variability in water quality.
\end{abstract}

Monthly water quality data for total suspended solids (TSS), total phosphorus (TP), filterable reactive phosphorus (FRP), total Kjedahl nitrogen (TKN), nitrate-nitrite $\left(\mathrm{NO}_{\mathrm{x}}\right)$ and electrical conductivity (EC), in addition to streamflow collected between 1994 and 2014 from 107 water quality monitoring sites in Victoria were used for this study. Using these data, we characterized the interaction between constituent concentrations and streamflow in terms of (i) the ratio of the coefficient of variation (CV) of constituent concentrations to the $\mathrm{CV}$ of streamflow $\left(\mathrm{CV}_{\mathrm{C}} / \mathrm{CV}_{\mathrm{Q}}\right)$, and (ii) the slope of the linear regression between the log-transformed constituent concentrations and log-transformed streamflow (the C-Q slope). We then linked the spatial variations in $\mathrm{CV}_{\mathrm{C}} / \mathrm{CV}_{\mathrm{Q}}$ and the $\mathrm{C}-\mathrm{Q}$ slope to catchment characteristics (e.g., land use and climate).

We found that the interaction between constituents and streamflow depends significantly on the reactivity of the constituent, and whether the constituent is in the dissolved or particulate state. TSS, TP, TKN, FRP and $\mathrm{NO}_{\mathrm{x}}$ demonstrated chemodynamic behavior, with the concentrations varying with streamflow (i.e., high $\mathrm{CV}_{\mathrm{C}} / \mathrm{CV}_{\mathrm{Q}}$ and large absolute value in $\mathrm{C}-\mathrm{Q}$ slope). On the other hand, EC demonstrated chemostatic behavior for the selected sites, with low $\mathrm{CV}_{\mathrm{C}} / \mathrm{CV}_{\mathrm{Q}}$ values and $\mathrm{C}-\mathrm{Q}$ slopes.

The interaction between streamflow and constituents varied significantly across space. The variability in $\mathrm{CV}_{\mathrm{C}} / \mathrm{CV}_{\mathrm{Q}}$ for TSS, nutrients and salts correlated positively with catchment characteristics such as mean catchment slope, average annual rainfall and woodland cover. This could be due to the weaker sources of TSS due to reduced erosion, nutrients due to zero or low application and salts due to high leaching in steeply sloping, vegetated and high rainfall catchments (as they tend to be less disturbed). Lower magnitude and less temporal consistency of constituent sources can lead to greater variability in constituent concentrations relative to streamflow. The spatial variability in C-Q slopes generally did not correlate strongly to catchment characteristics, likely due to the presence of major dams in approximately half of the water quality monitoring sites. However, once these sites were removed, we found that the TSS C-Q slope correlated strongly to average annual rainfall and the mean 7-day low flow. This suggests that there is a stronger positive linear relationship between TSS concentrations and streamflow in catchments with temporally consistent rainfall and streamflow. There were weak correlations between catchment characteristics and the $\mathrm{C}-\mathrm{Q}$ slopes for nutrients regardless of the exclusion of the water quality monitoring sites with dams. This could be due to the reactive nature of these compounds, leading to less predictable interactions between streamflow and in-stream concentrations.

The results of the analysis will be used to develop statistically-based predictive models of spatio-temporal variability in stream water quality.

Keywords: Stream water quality, spatial variability, temporal changes, catchment dynamics 


\section{INTRODUCTION}

Globally, rivers and streams are experiencing a decrease in water quality, with increasing concentrations of sediment, nutrient and salt concentrations (Schwarzenbach et al., 2010). Management strategies to decrease the pollution levels in these freshwater aquatic systems are required, as poor water quality not only undermines environmental values, but can also lead to water security problems for humans (Jiang, 2009; Vorosmarty et al., 2010). To implement successful management strategies, we need a clear understanding of the key factors affecting both spatial and temporal variability in stream water quality.

We previously developed statistical models of spatial variability in water quality (Lintern et al., in preparation), whereby catchment characteristics were used to predict time-averaged in-stream sediment, nutrient and salt concentrations. The performance of these models could potentially be improved by accounting for temporal variations in water quality, and the extent of spatial differences in seasonal water quality trends.

Sediment, nutrient and salt concentrations in rivers vary over time. This can be a result of various climatic, hydrologic and dynamic land cover, use and management factors. However, streamflow is generally used as the key temporal predictor for water quality (Vaze et al., 2004). In addition, previous studies have identified that the relationship between discharge and nutrients (total phosphorus; TP and total nitrogen; TN) can vary spatially (e.g., Donohue et al., 2005). In a study of 14 riverine sites in Ireland, Donohue et al. (2005) found a positive relationship between the molybdate reactive phosphorus-flow relationship and soil P levels. Spatial differences in the discharge-nutrient relationship are also likely a result of the effect of soil moisture, as soil moisture can affect the nature of the relationship between constituent concentrations and flow (Whitehead et al., 1998). There is still limited insight however, as to how discharge-constituent relationships vary across space, not just for nutrients, but also for suspended solids and electrical conductivity.

As such, the aim of this investigation was to:

- identify the interaction between water quality constituent concentrations and streamflow; and

- determine the catchment factors affecting spatial variability in these interactions.

This study focused on six common constituents that are known to have negative effects on stream water quality at elevated concentrations (Lintern et al., in press): total suspended solids, (TSS), total phosphorus (TP), filterable reactive phosphorus (FRP), total Kjedahl nitrogen $(\mathrm{TKN})$, nitrate-nitrite $\left(\mathrm{NO}_{\mathrm{x}}\right)$, electrical conductivity (EC). Understanding the factors affecting spatial variability in the relationships between streamflow and constituent concentrations can help us model and further build our understanding of spatiotemporal water quality variability that can be expected in the future under different land management and climate change scenarios.

\section{METHODOLOGY}

Monthly measurements of TSS, TP, FRP, TKN, $\mathrm{NO}_{\mathrm{X}}$ and $\mathrm{EC}$ at 107 stream water quality sites in Victoria (1994-2014) were obtained from the Water Measurement Information System (Department of Environment, Land, Water and Planning Victoria, 2016). Streamflow measurements corresponding to each water quality sample were also obtained from the database. The 107 sites had catchment areas ranging from $5 \mathrm{~km}^{2}$ to $16,000 \mathrm{~km}^{2}$ (as determined by the Geofabric tool provided by the Bureau of Meteorology (2012), and are located throughout the State of Victoria (Figure 1).

For the catchments corresponding to each water quality site, land use, land cover, topographic, climatic, geological, lithological and hydrological catchment characteristics were obtained from Geoscience Australia (2011, 2004), the Bureau of Meteorology (2012), the Bureau of Rural Sciences (2010), the Victorian 
Department for Environment, Land, Water and Planning (2014; 2016), and the Terrestrial Ecosystem Research Network (2016). Fifty different catchment characteristics were obtained from these datasets.

We explored the relationship between streamflow and water quality constituent concentrations using the method outlined in Musolff et al. (2015). We performed a linear regression using log-transformed data between discharge and constituent concentrations at each of the 107 sites (Equation 1). In Equation 1, C represents the constituent concentrations and $Q$ represents the discharge corresponding to the water quality measurement, $a$ is the intercept term, and $b$ is the slope term describing the strength of the relationship between $C$ and $Q$. As such, $b$ can give an indication of the strength of the linearity between constituent concentrations and streamflow. In the rest of the study, this is referred to as the ' $\mathrm{C}-\mathrm{Q}$ slope'.

$$
\ln (C)=a+b \ln (Q)
$$

For each site, we then calculated the ratio between the coefficient of variation of the constituent concentrations $\left(\mathrm{CV}_{\mathrm{C}}\right)$ and the coefficient of variation of discharge $\left(\mathrm{CV}_{\mathrm{Q}}\right)$ using the untransformed data. Large values of $\mathrm{CV}_{\mathrm{C}} / \mathrm{CV}_{\mathrm{Q}}$ represent chemodynamic behaviour (i.e., large variability in constituent concentrations compared to discharge) and low values represent chemostatic behaviour. To better understand the spatial variability in the interaction between streamflow and water quality constituents, we identified the Spearman Rank Correlation Coefficients $(\alpha=0.05)$ between the $\mathrm{CV}_{\mathrm{C}} / \mathrm{CV}_{\mathrm{Q}}$ and the $\mathrm{C}-\mathrm{Q}$ slope to catchment characteristics for each site. We report both the Spearman Rank Correlation Coefficients ( $\rho)$ and the p-values (p).

\section{RESULTS AND DISCUSSION}

\subsection{How do constituent concentrations respond to streamflow?}

TSS and TP have highly chemodynamic behavior.

Both TSS and TP exhibit high variability in concentration relative to discharge, with the 97.5th percentile of $\mathrm{CV}_{\mathrm{C}} / \mathrm{CV}_{\mathrm{Q}}$ across the 107 sites being greater than 4 for both TSS and TP (Table 1). In fact, $\mathrm{CV}_{\mathrm{C}} / \mathrm{CV}_{\mathrm{Q}}$ is as large as 7 for TSS and 6.1 for TP, which indicates that the variability in TSS and TP concentrations greatly exceeds the variability in flow at some water quality monitoring sites. This suggests that temporal variability in TSS and TP cannot be solely explained by streamflow. Instead, it is affected also by temporal factors such as rainfall, antecedent dry weather period or temperature (Lecce et al., 2006; Robson, 2014), or local factors such as sediment phosphorus release and sediment erosion.

Table 1. Summary statistics of the $\mathrm{CV}_{\mathrm{C}} / \mathrm{CV}_{\mathrm{Q}}$ and $\mathrm{C}-\mathrm{Q}$ slope $(b)$ calculated for the 107 water quality sites.

\begin{tabular}{|c|c|c|c|c|c|c|}
\hline & & $2.5^{\text {th }}$ percentile & Median & $97.5^{\text {th }}$ percentile & $\%$ of $C V_{C} / C V_{Q}$ above 1 & \% of $b$ above 0 \\
\hline \multirow{6}{*}{$\mathrm{CV}_{\mathrm{C}} / \mathrm{CV}_{\mathrm{Q}}$} & TSS & 0.20 & 0.66 & 4.9 & 35 & \\
\hline & TP & 0.16 & 0.46 & 4.3 & 19 & \\
\hline & FRP & 0.15 & 0.48 & 1.9 & 17 & \\
\hline & TKN & 0.077 & 0.26 & 2.2 & 15 & \\
\hline & NO $_{x}$ & 0.23 & 0.63 & 2.2 & 21 & \\
\hline & EC & 0.057 & 0.18 & 0.74 & 1.9 & \\
\hline \multirow{6}{*}{$\begin{array}{c}\text { C-Q } \\
\text { slope, } b\end{array}$} & TSS & -0.036 & 0.19 & 0.58 & & 93 \\
\hline & TP & -0.091 & 0.096 & 0.32 & & 78 \\
\hline & FRP & -0.21 & 0.031 & 0.35 & & 70 \\
\hline & TKN & -0.11 & 0.061 & 0.37 & & 85 \\
\hline & NO $_{x}$ & -0.029 & 0.47 & 0.96 & & 96 \\
\hline & EC & -0.26 & -0.11 & 0.048 & & 8 \\
\hline
\end{tabular}

The high $\mathrm{CV}_{\mathrm{C}} / \mathrm{CV}_{\mathrm{Q}}$ values for TSS and TP at some Victorian sites might also be a result of changes in water quality following bushfires. In particular, the high $\mathrm{CV}_{\mathrm{C}} / \mathrm{CV}_{\mathrm{Q}}$ values at the Macallister River (Site 225209, $\mathrm{CV}_{\mathrm{C}} / \mathrm{CV}_{\mathrm{Q}}=7$ ), Wonnangatta River (224206, $\left.\mathrm{CV}_{\mathrm{C}} / \mathrm{CV}_{\mathrm{Q}}=7\right)$, Ovens River (403210, $\mathrm{CV}_{\mathrm{C}} / \mathrm{CV}_{\mathrm{Q}}=5.3$ ), Dargo River $\left(224213, \mathrm{CV}_{\mathrm{C}} / \mathrm{CV}_{\mathrm{Q}}=4.7\right)$, Mitchell River $\left(224203, \mathrm{CV}_{\mathrm{C}} / \mathrm{CV}_{\mathrm{Q}}=4\right)$, Nariel Creek $\left(401212, \mathrm{CV}_{\mathrm{C}} / \mathrm{CV}_{\mathrm{Q}}\right.$ = 3.8), Tambo River (223202, $\mathrm{CV}_{\mathrm{C}} / \mathrm{CV}_{\mathrm{Q}}=3.8$ ), and Snowy River $\left(222209, \mathrm{CV}_{\mathrm{C}} / \mathrm{CV}_{\mathrm{Q}}=3.3\right.$ ), appear to be affected by high TSS and TP concentrations measured at the site within 6 months after a bushfire event. The occurrence of fire in the catchment can result in increased suspended sediment stores in the catchment (due to ash deposition) as well as increased erosion (due to the reduction in vegetation cover). As such, TSS concentrations generally increase in the first stormflow after fires (Smith et al., 2011). TP may also be experiencing elevated concentrations after fires due to its association with particulate matter. Higher TP concentrations were recorded in the first year after fire in four reservoirs in Victoria (Smith et al., 2011). 


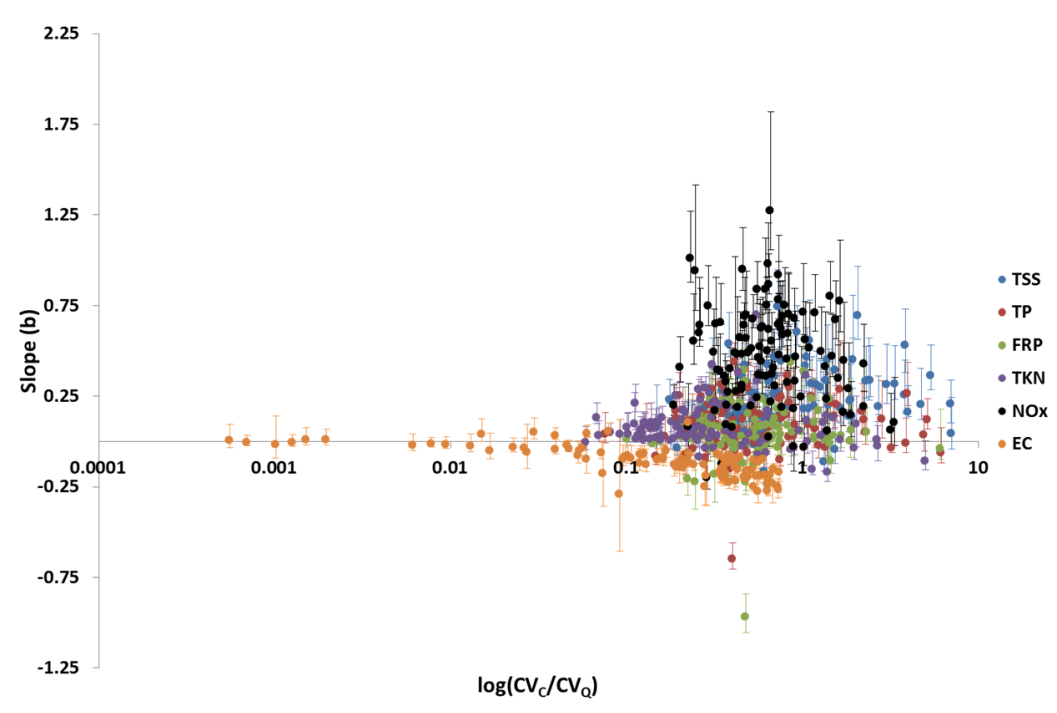

Figure 2. Relationship between $\mathrm{CV}_{\mathrm{C}} / \mathrm{CV}_{\mathrm{Q}}$ and linear regression slope for TSS, TP, FRP, TKN, $\mathrm{NO}_{\mathrm{x}}$ and EC.
The C-Q slope is generally positive for both TSS and TP, indicating an increase in TSS and TP concentrations with streamflow at most sites (Figure 2). However, these linear relationships are generally weak. The median value of the $\mathrm{C}-\mathrm{Q}$ slope across the 107 sites is 0.19 for TSS and 0.10 for TP (Table 1). Musolff et al. (2015) also found weakly positive C-Q slopes for TSS in German stream catchments. The similarity between TSS and TP in their response to discharge both in terms of the C-Q slope, and

$\mathrm{CV}_{\mathrm{C}} / \mathrm{CV}_{\mathrm{Q}}$ is likely due to the particulate nature of TP. Due to the fact that phosphorus is generally found in the particulate form, previous studies have noticed that TSS and TP concentrations in streams are driven by similar sources, and mobilization and delivery processes (Ekholm et al., 2000; Schoumans et al., 2014).

FRP, TKN and $N O_{x}$ have moderately chemostatic behavior.

FRP, TKN and $\mathrm{NO}_{x}$ have lower $\mathrm{CV}_{\mathrm{C}} / \mathrm{CV}_{\mathrm{Q}}$ values compared to TSS and TP, with the $97.5^{\text {th }}$ percentile of $\mathrm{CV}_{\mathrm{C}} / \mathrm{CV}_{\mathrm{Q}}$ being between 1.9 and 2.2 (Table 1). This suggests that variations in FRP, TKN and $\mathrm{NO}_{\mathrm{x}}$ concentrations relative to streamflow are less than that of TSS and TP. This could be suggesting that FRP, TKN and $\mathrm{NO}_{\mathrm{x}}$ fluctuations in streams are less affected by bushfires. However, further investigations into nutrient fluxes from catchments after bushfires would be required to confirm this.

There is a low C-Q slope for FRP and TKN for most catchments (Figure 2). The median C-Q slopes for FRP and TKN across the 107 catchments are 0.03 and 0.06 , respectively (Table 1). The weak linear relationship between discharge and either FRP or TKN may be due to the fact that FRP and TKN are reactive compounds, and as such, their mobilisation from the catchment can be significantly affected by several land use, climatic and hydrological factors. Additional temporal factors such as temperature and soil moisture, which affect the transformation of FRP and TKN can influence the delivery and mobilization of these compounds from the catchment to receiving rivers (Butler et al., 2012; Hanrahan et al., 2003).

At most sites, $\mathrm{NO}_{\mathrm{x}}$ has a positive $\mathrm{C}-\mathrm{Q}$ slope, which indicates that $\mathrm{NO}_{\mathrm{x}}$ is generally positively correlated to streamflow (Figure 2 and Table 1). This suggests that temporal variability of $\mathrm{NO}_{\mathrm{x}}$ in rivers and streams is largely governed by discharge, and that other climatic and hydrological factors (e.g., temperature and soil moisture) are not as important. This is surprising, given the transformations that $\mathrm{NO}_{\mathrm{x}}$ can undergo (Creed and Beall, 2009). However, Musolff et al. (2015) also had similar results, whereby $\mathrm{NO}_{\mathrm{x}} \mathrm{C}-\mathrm{Q}$ slopes were found to be strongly positive. They suggested that in developed catchments with drains (e.g., catchments with high agricultural land use), discharge is the key determinant of transport and mobilization of $\mathrm{NO}_{\mathrm{x}}$. Similarly, this positive slope could be due to the mobilization and delivery of $\mathrm{NO}_{\mathrm{x}}$ in interflow or surface runoff.

\section{EC has chemostatic behavior.}

The $\mathrm{CV}_{\mathrm{C}} / \mathrm{CV}_{\mathrm{Q}}$ value of EC is lower than that of TSS and nutrients (TP, FRP, TKN and $\mathrm{NO}_{\mathrm{x}}$ ) (Table 1 and Figure 2). Salts can exhibit chemostatic behavior because of the large amounts stored within the catchment, which allow temporally consistent transport to receiving waters (Musolff et al., 2015). The negative C-Q slopes for EC (Figure 2), also suggest that in most catchments, there is a constant salt supply into streams delivered by baseflow, which can be diluted by sudden increases in discharge (Vaze et al., 2004).

\subsection{What drives the spatial variability in the interactions between flow and constituent concentrations?}

Catchment characteristics correlate strongly to $C V_{C} / C V_{Q}$. 
For TSS, TP and TKN, there are strong positive correlations between $\mathrm{CV}_{\mathrm{C}} / \mathrm{CV}_{\mathrm{Q}}$ and mean catchment slope and mean annual rainfall (Table 2). For EC, the strongest correlations are also between $C V_{C} / C V_{Q}$ and mean catchment slope, and mean annual rainfall. This suggests that in catchments with steeper slopes and catchments that are wetter, there is a greater variability in TSS, TP and TKN relative to discharge. There are several possible explanations for this. Firstly, steep slopes and greater rainfall depths could lead to more variability in the mobilization of particulate constituents depending on the shear stress applied by rainfall and runoff. Secondly, there is a positive cross-correlation between catchment slope, mean annual rainfall and the proportion of the catchment that has been cleared for pasture $(\rho<-0.67, p<0.05)$. In less disturbed catchments, these constituents have smaller stores and can vary more than flow because of the influence of temporal factors such as rainfall, antecedent dry weather or fire (Musolff et al., 2015). In contrast, it is possible that in agricultural areas, more disturbed areas or areas with lower catchment slopes, sediment supply is relatively consistent, which would decrease the variability in TSS. This hypothesis also seems to support the positive correlation between $\mathrm{CV}_{\mathrm{C}} / \mathrm{CV}_{\mathrm{Q}}$ for $\mathrm{EC}$ and average annual rainfall and catchment slope, and the positive correlation between the $\mathrm{CV}_{\mathrm{C}} / \mathrm{CV}_{\mathrm{Q}}$ for $\mathrm{NO}_{\mathrm{x}}$ and the proportion of the catchment covered in woodland (Table 2). In general, it appears that in steep and wet (typically undeveloped) catchments, large temporal variability in particulate constituent concentrations are due to limitations in supply of particulates. However, in flat and dry catchments (typically under greater human influences), temporal variability appears to be controlled by transport processes, which may lead to lower temporal variability in particulate concentrations.

Table 2. Correlations between the $\mathrm{CV}_{\mathrm{C}} / \mathrm{CV}_{\mathrm{Q}}$ ratio and selected catchment characteristics

\begin{tabular}{|l|c|r|r|r|r|r|}
\hline & TSS & TP & FRP & \multicolumn{1}{|c|}{ TKN } & NO $_{\mathbf{x}}$ & \multicolumn{1}{|c|}{ EC } \\
\hline Average annual rainfall (mm) & 0.64 & 0.56 & 0.26 & 0.74 & 0.16 & 0.40 \\
\hline Mean 7-day low flow (ML/d) & 0.23 & 0.38 & 0.30 & 0.47 & 0.04 & 0.17 \\
\hline Woodland cover in catchment (\%) & 0.24 & 0.36 & 0.17 & 0.32 & 0.39 & 0.09 \\
\hline Mean soil TP content (mg/kg) & 0.41 & 0.34 & 0.33 & 0.57 & 0.13 & 0.29 \\
\hline Mean catchment slope (\%) & 0.61 & 0.65 & 0.24 & 0.71 & 0.28 & 0.30 \\
\hline
\end{tabular}

Catchment characteristics correlate weakly to $C-Q$ slope.

There were weak correlations between the C-Q slope and catchment characteristics for most constituents. This could be due to the fact that at least half of the sites included in the analysis have dams within their catchments. With the presence of dams, constituent transport by streamflow is altered and would therefore be less predictable using catchment characteristics. It should be noted though that EC has a strong correlation between the C-Q slope and the proportion of the catchment area forested $(\rho=0.5, p<0.05)$. The fact that only EC has a strong correlation between catchment characteristics and the C-Q slope, regardless of the presence of dams, could be an indication that the salt loads are generally entering streams downstream of the dams.

However, when the sites with dams are removed from the analysis, the strength of the correlations between catchment characteristics and the C-Q slopes increases. For TSS, there is an increase in the correlation between the annual average rainfall, mean 7-day low flow and the TSS C-Q slope (Table 3). When catchments are wetter and have consistent streamflow temporally, extended dry weather periods where sediments can build up in the catchment are less likely (Bertrand-Krajewski et al., 1998).

When catchments with dams were excluded, the slope of the linear regression of nutrients (TP, FRP, TKN, $\mathrm{NO}_{\mathrm{x}}$ ) concentrations and discharge were weakly $(\rho<|0.5|)$ correlated to catchment characteristics. This suggests that the relationships between discharge and nutrients are not controlled by the catchment characteristics studied. It is possible that they are controlled by catchment characteristics not considered here (e.g., microbial activity in the rhizosphere in the catchment). It is also possible that the relationship between discharge and nutrients cannot be explained by spatial variables due to the large temporal variation that occurs as a result of factors other than flow (Musolff et al., 2015).

Table 3. Correlations between C-Q slope and catchment characteristics for sites without water storages

\begin{tabular}{|l|r|r|r|r|r|r|}
\hline & TSS & \multicolumn{1}{|c|}{ TP } & \multicolumn{1}{c|}{ FRP } & \multicolumn{1}{c|}{ TKN } & \multicolumn{1}{c|}{ NO } & \multicolumn{1}{|c|}{ EC } \\
\hline Average annual rainfall (mm) & $0.50^{* *}$ & -0.08 & -0.21 & -0.32 & -0.13 & $0.39^{* *}$ \\
\hline Mean 7-day low flow (ML/d) & $0.65^{* *}$ & 0.02 & -0.31 & 0.07 & -0.02 & $0.41^{* *}$ \\
\hline Agricultural land use in catchment (\%) & $-0.28^{*}$ & 0.17 & $0.41^{* *}$ & 0.16 & $0.29^{*}$ & $-0.23^{* *}$ \\
\hline Cropping land use in catchment (\%) & $-0.33^{*}$ & $0.27^{*}$ & $0.39^{* *}$ & $0.21^{*}$ & 0.14 & $-0.48^{* *}$ \\
\hline Forest cover in catchment (\%) & $0.30^{*}$ & -0.15 & $-0.30^{* *}$ & $-0.19^{*}$ & -0.04 & $0.56^{* *}$ \\
\hline Shrub cover in catchment (\%) & -0.02 & -0.28 & -0.01 & 0.04 & $-0.44^{* *}$ & -0.02 \\
\hline Woodland cover in catchment (\%) & -0.14 & 0.01 & 0.01 & -0.02 & $-0.41^{* *}$ & -0.36 \\
\hline Mean catchment elevation (m) & 0.15 & $-0.21^{*}$ & $-0.26^{* *}$ & $-0.45^{* *}$ & -0.18 & \\
\hline
\end{tabular}

$* * p<0.01 ; * p<0.05$ 


\section{CONCLUSIONS AND FUTURE WORK}

The aim of this investigation was to identify the relationships between streamflow and constituent concentrations (TSS, TP, FRP, TKN, NO, EC) in 107 catchments across the state of Victoria and to determine the key catchment characteristics affecting spatial variability in these relationships. We used two metrics to describe the interaction between streamflow and constituent concentrations: $\mathrm{CV}_{\mathrm{C}} / \mathrm{CV}_{\mathrm{Q}}$ and the $\mathrm{C}-\mathrm{Q}$ slope. Using these metrics, we found that the constituents' responses to flow vary depending on whether they are reactive, particulate, dissolved or conservative. For example, whilst TSS, TP, TKN, FRP and $\mathrm{NO}_{\mathrm{x}}$, which are reactive and/or particulate bound constituents exhibited chemodynamic behavior (high C-Q slopes and/or high $\mathrm{CV}_{\mathrm{C}} / \mathrm{CV}_{\mathrm{Q}}$ ratios), $\mathrm{EC}$, which is more conservative and exists in solute forms showed the opposite.

The magnitude of the ratio between variability in concentration and flow $\left(\mathrm{CV}_{\mathrm{C}} / \mathrm{CV}_{\mathrm{Q}}\right)$ correlated with catchment characteristics. In particular, high $\mathrm{CV}_{\mathrm{C}} / \mathrm{CV}_{\mathrm{Q}}$ for $\mathrm{TSS}, \mathrm{TP}, \mathrm{TKN}, \mathrm{NO}_{\mathrm{x}}$ and $\mathrm{EC}$ occurred in 'more natural' catchments. On the other hand, there were generally weaker relationships between the C-Q slope and catchment characteristics. When the catchments with dams were removed from the analysis, we identified that there are stronger linear relationships between Q and TSS constituents in catchments where the delivery of the constituent is consistent (temporally) and the catchment is generally wetter.

We intend to use the results of the data analysis presented here to develop statistically-based predictive models of spatio-temporal variability in stream water quality. It appears that spatial differences in the linear relationship between TSS, EC and streamflow can be linked to catchment characteristics. Similarly, the catchment characteristics can help explain spatial differences in the interactions between TP, TKN and streamflow, when these streamflow-water quality interactions are characterized by $\mathrm{CV}_{\mathrm{C}} / \mathrm{CV}_{\mathrm{Q}}$. However, modelling spatial differences in the temporal variability in FRP and $\mathrm{NO}_{\mathrm{x}}$ concentrations requires further investigation. It is possible that considering the effect of additional temporal climatic and hydrologic factors (e.g., rainfall, soil moisture) on in-stream FRP and $\mathrm{NO}_{\mathrm{x}}$ concentrations may enable us to link temporal variability in FRP and $\mathrm{NO}_{\mathrm{x}}$ to catchment characteristics.

\section{ACKNOWLEDGMENTS}

This project has been supported by the Australian Research Council, the Victorian EPA, the Victorian Department of Environment, Land Water and Planning, the Bureau of Meteorology and the Queensland Department of Natural Resources and Mines (LP140100495). The authors would also like to offer gratitude to Matthew Johnson, Louise Sullivan and Jie Jian for their assistance in data compilation and analysis.

\section{REFERENCES}

Bertrand-Krajewski, J.-L., Chebbo, G., Saget, A. (1998). Distribution of pollutant mass vs volume in stormwater discharges and the first flush phenomenon. Water Res. 32, 2341-2356. doi:http://dx.doi.org/10.1016/S0043-1354(97)00420-X

Bureau of Meteorology, (2012). Geofabric V2 [WWW Document]. URL ftp://ftp.bom.gov.au/anon/home/geofabric/ (accessed 9.21.16).

Bureau of Rural Sciences (2010). 2005/06 Land Use of Australia, Version 4 [WWW Document]. URL http://www.agriculture.gov.au/abares/aclump/land-use/data-download (accessed 9.1.16).

Butler, S.M., Melillo, J.M., Johnson, J.E., Mohan, J., Steudler, P.A., Lux, H., Burrows, E., Smith, R.M., Vario, C.L., Scott, L., Hill, T.D., Aponte, N., Bowles, F. (2012). Soil warming alters nitrogen cycling in a New England forest: implications for ecosystem function and structure. Oecologia 168, 819-828.

Creed, I.F., Beall, F.D. (2009). Distributed topographic indicators for predicting nitrogen export from headwater catchments. Water Resour. Res. 45, n/a-n/a. doi:10.1029/2008WR007285

Department of Environment, Land, Water and Planning Victoria (2016). Victorian water measurement information system [WWW Document]. URL http://data.water.vic.gov.au/monitoring.htm (accessed 6.20.02).

Department of Environment Land Water and Planning (2014). Index of condition system [WWW Document]. URL http://ics.water.vic.gov.au/ics/ (accessed 9.27.16).

Department of Environment Land Water and Planning Victoria (2016). Farm dam boundaries [WWW Document]. URL https://www.data.vic.gov.au/data/dataset/farm-dam-boundaries (accessed 8.10.16). 
Donohue, I., Styles, D., Coxon, C., Irvine, K. (2005). Importance of spatial and temporal patterns for assessment of risk of diffuse nutrient emissions to surface waters. J. Hydrol. 304, 183-192.

Ekholm, P., Kallio, K., Salo, S., Pietiläinen, O.-P., Rekolainen, S., Laine, Y., Joukola, M. (2000). Relationship between catchment characteristics and nutrient concentrations in an agricultural river system. Water Res. 34, 3709-3716. doi:http://dx.doi.org/10.1016/S0043-1354(00)00126-3

Geoscience Australia (2011). Environmental Attributes Database [WWW Document]. URL http://www.ga.gov.au (accessed 2.5.16).

Geoscience Australia (2004). Dams and Water Storages [WWW Document]. URL http:/www.ga.gov.au/metadata-gateway/metadata/record/gcat_a05f7892-b795-7506-e04400144fdd4fa6/Dams+and+water+storages+1990 (accessed 9.1.16).

Hanrahan, G., Gledhill, M., House, W.A., Worsfold, P.J. (2003). Evaluation of phosphorus concentrations in relation to annual and seasonal physico-chemical water quality parameters in a UK chalk stream. Water Res. 37, 3579-3589. doi:http://dx.doi.org/10.1016/S0043-1354(03)00265-3

Jiang, Y. (2009). China's water scarcity. J. Environ. Manage. 90, 3185-3196. doi:http://dx.doi.org/10.1016/j.jenvman.2009.04.016

Lecce, S.A., Pease, P.P., Gares, P.A., Wang, J. (2006). Seasonal controls on sediment delivery in a small coastal plain watershed, North Carolina, USA. Geomorphology 73, 246-260. doi:http://dx.doi.org/10.1016/j.geomorph.2005.05.017

Lintern, A., Webb, J.A., Ryu, D., Liu, S., Bende-Michl, U., Waters, D., Leahy, P., Wilson, P., Western, A.W., What are the key catchment characteristics affecting riverine water quality?, (in preparation)

Lintern, A., Webb, J.A., Ryu, D., Liu, S., Bende-Michl, U., Waters, D., Leahy, P., Wilson, P., Western, A.W., in press, Key factors influencing differences in stream water quality across space. Wires Water.

Musolff, A., Schmidt, C., Selle, B., Fleckenstein, J.H. (2015). Catchment controls on solute export. $A d v$. Water Resour. 86, Part A, 133-146. doi:http://dx.doi.org/10.1016/j.advwatres.2015.09.026

Robson, B.J. (2014). State of the art in modelling of phosphorus in aquatic systems: Review, criticisms and commentary. Environ. Model. Softw. 61, 339-359. doi:http://dx.doi.org/10.1016/j.envsoft.2014.01.012

Schoumans, O.F., Chardon, W.J., Bechmann, M.E., Gascuel-Odoux, C., Hofman, G., Kronvang, B., Rubæk, G.H., Ulén, B., Dorioz, J.-M. (2014). Mitigation options to reduce phosphorus losses from the agricultural sector and improve surface water quality: A review. Sci. Total Environ. 468-469, 12551266. doi:http://dx.doi.org/10.1016/j.scitotenv.2013.08.061

Schwarzenbach, R.P., Egli, T., Hofstetter, T.B., von Gunten, U., Wehrli, B. (2010). Global Water Pollution and Human Health. Annu. Rev. Environ. Resour. 35, 109-136. doi:10.1146/annurev-environ-100809125342

Smith, H.G., Sheridan, G.J., Lane, P.N.J., Nyman, P., Haydon, S. (2011). Wildfire effects on water quality in forest catchments: A review with implications for water supply. J. Hydrol. 396, 170-192. doi:http://dx.doi.org/10.1016/j.jhydrol.2010.10.043

Terrestrial Ecosystem Research Network (2016). Soil and Landscape Grid of Australia [WWW Document]. URL http://www.clw.csiro.au/aclep/soilandlandscapegrid/index.html (accessed 7.7.16).

Vaze, J., Barnett, P., Beale, G., Dawes, W., Evans, R., Tuteja, N.K., Murphy, B., Geeves, G., Miller, M. (2004). Modelling the effects of land-use change on water and salt delivery from a catchment affected by dryland salinity in south-east Australia. Hydrol. Process. 18, 1613-1637. doi:10.1002/hyp.1409

Vorosmarty, C.J., McIntyre, P.B., Gessner, M.O., Dudgeon, D., Prusevich, A., Green, P., Glidden, S., Bunn, S.E., Sullivan, C.A., Liermann, C.R., Davies, P.M. (2010). Global threats to human water security and river biodiversity. Nature 467, 555-561.

Whitehead, P.G., Wilson, E.J., Butterfield, D. (1998). A semi-distributed Integrated Nitrogen model for multiple source assessment in Catchments (INCA): Part I - model structure and process equations. Sci. Total Environ. 210-211, 547-558. 